\title{
PRELIMINARY ASSESSMENT OF IMPACT OF ROUNDWOOD FORWARDING ON SOIL WATER PERMEABILITY AND WATER TABLE LEVEL IN COMMERCIAL THINNINGS ON MINERAL SOILS
}

\author{
Janis Ivanovs $^{1}$, Raitis Melniks ${ }^{1}$, Jelena Stola ${ }^{1}$, Olga Frolova ${ }^{2}$ \\ ${ }^{1}$ Latvian State Forest Research Institute "Silava", Latvia; ${ }^{2}$ Latvia University of Life Sciences and \\ Technologies, Latvia \\ janis.ivanovs@silava.lv, raitis.melniks@silava.lv, jelena.stola@silava.lv, olga.frolova@llu.lv
}

\begin{abstract}
The aim of the study is to evaluate the impact of forest harvesting machinery on soil compaction in technological corridors and on water exchange. The study area consists of 6 study plots on sandy and moraine loam sediments. Each study site is $400 \mathrm{~m}^{2}$ large and consists of a $20 \mathrm{~m}$ long technological corridor with adjoining areas. Thinning has been done in the study areas in 2016 and technological corridors are made perpendicular to slope of the forest floor. During field works data about soil penetration resistance were collected. Monitoring of the groundwater level was conducted during all study period and soil samples were collected to analyse the soil water permeability. The study concludes that, due to logging, there are significant signs of soil compaction in technological corridors. In the study sites on the sandy sediments the greatest compaction effect is observed in the layer from $20-80 \mathrm{~cm}$, while on the moraine loam sediments in the layer up to $20 \mathrm{~cm}$ deep. Changes in groundwater levels as a result of soil compaction have not been observed and that may be associated with atypically dry weather conditions during 2018.
\end{abstract}

Keywords: soil compaction, water table, groundwater flow.

\section{Introduction}

Several studies [1-3] conclude that heavy logging machinery significantly contributes to soil compaction and decreases the amount of macropores in soil, hinders water infiltration and gas exchange, and affects adjacent areas. Significant impact has also been observed on the soil fauna. The most significant effects of heavy machinery are found on wet soil, where changes in the amount of macropores are found even deeper than $70 \mathrm{~cm}$ from the surface of the soil and its recovery in all cases is slow.

In Latvia, studies on the impact of changes in groundwater levels in forests have been started already in 1959 [4;5]. Short-term changes in groundwater levels have been observed to have no significant impact on tree growth conditions, but long-term increases or decreases are not desirable.

Forestry tends to use increasingly powerful and heavier machinery, which in turn promotes soil degradation processes. Forest machinery causes increased pressure on soil, vibration and shear, resulting in soil compaction and structural changes [6]. These processes contribute to reduction of soil porosityby about $20 \%$ [7]. Subsequently, an increase in the bulk volume has also been observed, which interacts with the reduction in the pore size to promote water retention and limit aeration. A prerequisite for sufficient aeration, microorganism activity and root development is that macropores in soil should occupy at least $10 \%$ of total volume [8].

Compaction also means an increase in the penetration resistance and decrease in the electrical conductivity and the soil water permeability rate [9]. This type of disturbance in water and air exchange in soil can contribute to changes in chemical processes, thus limiting the availability of nutrients to plants $[10 ; 11]$.

Ruts slow down the development of tree roots and limit their spread by deteriorating the ability of roots to absorb water and nutrients [12]. These factors slow down the growth rate of trees and reduce plant survival [13]. The influence of these factors depends on the soil moisture regime and soil type, as well as the dominant tree species [14]. Rutting also influences potential changes in plant communities in forests [15].

Changes in soil physical parameters may also adversely affect the soil fauna, making movement of organisms more difficult and altering the feed base [16]. Given that the soil fauna plays an important role in mineralization processes, such changes indirectly affect soil fertility. These changes are most pronounced on clay and loamy soils [17]. Sandy soils are compacted more slowly, but also their recovery is slower. Soil regeneration to previous stage occurs mainly due to biological processes, but also physical processes - freezing and thawing [18]. It should be noted that sandy soils hold water 
very badly, even if they are compacted, moreover, they are mostly acidic and poor in nutrients, and that does not contribute to restoration of the soil structure [19].

Soil moisture is the only indicator of water availability in a tree stand. The circulation of substances between the abiotic and biotic forest components is characterized by the interrelation between the temperature, nutrient availability, moisture regime and aeration [20]. Soil moisture regime is the most important factor in determining the degree of soil compaction. In wet seasons, such as autumn and spring, the risk of soil compaction is higher [21].

Precipitation provides aeration for the soil and promotes root penetration. Water infiltration has a positive effect on biological processes in soil, but flooding of roots after rain can cause them to die. For example, necrosis of pine and spruce roots begins after just 3-5 days in underwater conditions, but recovery takes 2-4 weeks, depending on the degree of damage [4].

Physiological processes are also negatively affected by water deficiency in the soil, for example due to reduced groundwater levels. During the vegetation period, soil moisture is constantly changing under the influence of meteorological factors and its changes in small amounts do not significantly affect forest productivity. Short-term root flooding, which occurs several times during the vegetation season, usually does not affect the root system in the soil. In well-aerated soils, forest stand is able to regulate the groundwater level by intensifying transpiration [22].

\section{Materials and methods}

This study was conducted in 6 forest stands, where in 2016 forest machinery moved through the technological corridors and the topsoil layer was subjected to compaction process. The main condition in the selection of the study sites was that the longitudinal direction of the technological corridors is perpendicular to the slope in terrain. Three objects are located on sandy loam, 3 on sand. Information about the terrain was obtained using LiDAR (Light detecting and ranging) data provided by the Latvian Geospatial Information Agency.

Forest stands on Glacigenic (glacial moraine sediments) and Glaciolimnic sediments (glacial water basin sediments) were selected for the study (Fig. 1). The background map displays the spatial distribution of Quaternary sediments on the surface of soil at scale 1:200 000 [23].

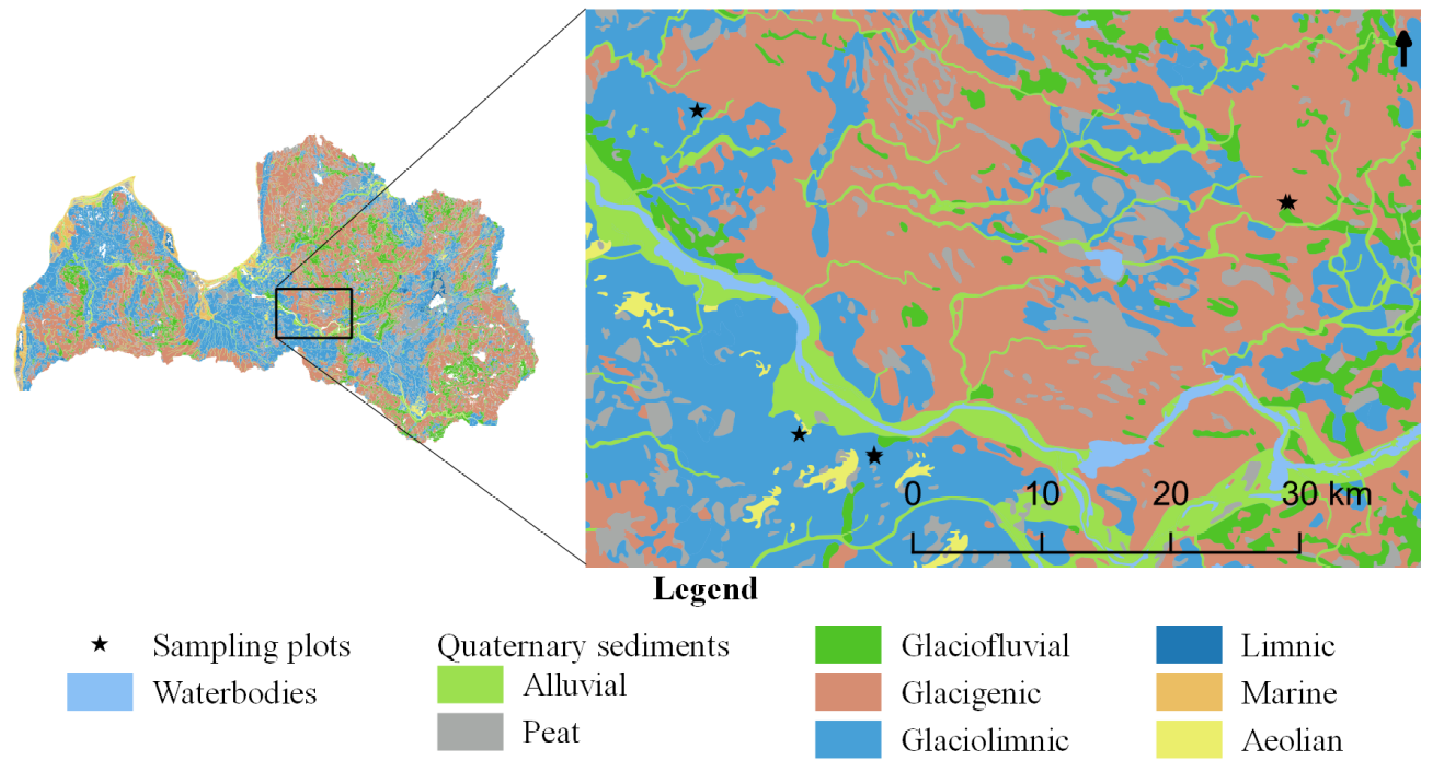

Fig. 1. Overview map of study site locations

Every study plot is $400 \mathrm{~m}^{2}(20 \times 20 \mathrm{~m})$ large. Soil penetration resistance measurements were performed with the Eijkelkamp penetrologger. Soil moisture measurements were not done, however, meteorological observations at the Skriveri meteorological observation station show that during the 10 day period before the measurements, there was periodic rainfall and a total rainfall of $12.1 \mathrm{~mm}$. Soil samples were collected at 4 different depths $(0-10 \mathrm{~cm}, 10-20 \mathrm{~cm}, 20-40 \mathrm{~cm}$ and $40-80 \mathrm{~cm})$ and they were taken from the technological corridor and on both sides of the corridor. 
There are 6 groundwater level monitoring wells in each study site (3 on both sides of the technological corridor). Groundwater level monitoring wells are designed to monitor the groundwater level fluctuations and differences on both sides of the technological corridors. Groundwater level monitoring has been carried out at 1 hour intervals for one year and was carried out in cooperation with specialists from the Latvia University of Life Sciences and Technologies. Water pressure was measured with the Vanessen instrument Mini-Diver. Air pressure was measured with Diver-DXT. Diver-Office software was used to read the data, and to do a pressure compensation procedure, which resulted in the height of the water column in the well. The diameter of the well is $75 \mathrm{~mm}$. The wells were set at ground level and average depth of wells was $1.52 \mathrm{~m}$.

The obtained soil samples have been analysed in laboratory. Density of different soil layers (LVS ISO 11272: 1998), soil texture composition (LVS ISO 11277: 2000) and soil water permeability have been analysed. Soil penetration resistance measurements, soil texture composition and soil water permeability rates were analysed in the context of technological corridors and adjacent areas, while the water table level monitoring data were viewed in pairs on both sides of the technological corridor. Precipitation and temperature data were taken from the website of the Latvian Environment, Geology and Meteorology Centre. Meteorological data were obtained at hourly intervals and the corresponding daily and average values were calculated.

\section{Results and discussion}

The analysis of the soil texture composition of the soil samples (Table 1) shows the proportion of soil particle fractions in different soil layers. The sand fraction dominates in Jaunjelgava objects, which makes up more than $90 \%$ of the soil mass in all analysed depths, but they also contain silt and clay particles. On the Ogresgals site, sand and silt sediments are predominantly present in the soil, but with increasing depth, the proportion of clay particles increases.

Table 1

Analysis of soil texture composition

\begin{tabular}{|c|c|c|c|c|c|}
\hline \multirow{2}{*}{ Soil texture } & \multirow{2}{*}{ Study object } & \multicolumn{4}{|c|}{ Depth, cm } \\
\hline & & $0-10$ & $10-20$ & $20-40$ & $40-80$ \\
\hline \multirow{6}{*}{$>2 \mathrm{~mm}, \%$} & Ogresgals & 0.2 & 0.1 & 0.0 & 0.2 \\
\hline & Vecbebri_2 & 0.4 & 0.7 & 1.0 & 1.3 \\
\hline & Vecbebri_1 & 0.5 & 0.5 & 1.9 & 7.6 \\
\hline & Jaunjelgava_3 & 0.0 & 0.0 & 0.0 & 0.0 \\
\hline & Jaunjelgava_2 & 0,0 & 0.0 & 0.0 & 0.0 \\
\hline & Jaunjelgava1 & 0.0 & 0.0 & 0.0 & 0.0 \\
\hline \multirow{6}{*}{$\begin{array}{c}2 \mathrm{~mm}-63 \\
\mu \mathrm{m}, \%\end{array}$} & Ogresgals & 43.6 & 43.3 & 29.3 & 27.0 \\
\hline & Vecbebri_2 & 60.0 & 60.4 & 62.8 & 59.7 \\
\hline & Vecbebri_1 & 62.2 & 59.7 & 61.7 & 69.2 \\
\hline & Jaunjelgava_3 & 98.0 & 95.5 & 95.2 & 93.3 \\
\hline & Jaunjelgava_2 & 97.9 & 97.3 & 96.4 & 95.7 \\
\hline & Jaunjelgava1 & 99.3 & 98.6 & 98.0 & 96.4 \\
\hline \multirow{6}{*}{$63-2 \mu \mathrm{m}, \%$} & Ogresgals & 46.2 & 41.3 & 47.5 & 54.3 \\
\hline & Vecbebri_2 & 30.6 & 30.8 & 29.0 & 22.8 \\
\hline & Vecbebri_1 & 28.0 & 32.1 & 31.4 & 18.9 \\
\hline & Jaunjelgava_3 & 1.5 & 3.9 & 4.0 & 4.5 \\
\hline & Jaunjelgava_2 & 1.9 & 2.6 & 3.0 & 3.7 \\
\hline & Jaunjelgava1 & 0.6 & 1.3 & 1.6 & 3.6 \\
\hline \multirow{6}{*}{$<2 \mu \mathrm{m}, \%$} & Ogresgals & 10.2 & 15.4 & 23.2 & 18.7 \\
\hline & Vecbebri_2 & 9.5 & 8.7 & 8.2 & 17.5 \\
\hline & Vecbebri_1 & 9.9 & 8.2 & 6.8 & 11.8 \\
\hline & Jaunjelgava_3 & 0.5 & 0.7 & 0.7 & 2.2 \\
\hline & Jaunjelgava_2 & 0.2 & 0.1 & 0.5 & 0.6 \\
\hline & Jaunjelgava1 & 0.1 & 0.1 & 0.4 & 0.0 \\
\hline
\end{tabular}


At all depths of Vecbebri sites the sand fraction is about $60 \%$ of the soil mass. As the depth increases, silt sediments are gradually replaced by clay. Gravel and pebble fractions are also found in Ogresgals and Vecbebri sites. Soil texture does not differ significantly in the samples collected on the technological corridors and on adjacent areas.

The results of the soil penetration resistance show increased values in the technological corridors in all of the study sites. Results from Jaunlelgava sites show significant increase in the soil penetration resistance due to soil compaction up to $80 \mathrm{~cm}$ deep. The results confirm the view expressed in other studies that soil compaction caused by logging machinery in sandy soils is more than $70 \mathrm{~cm}$ deep [1]. The study site in Ogresgals is more fertile than the sites in Jaunjelgava and default soil penetration resistance is lower because of smaller soil particle sizes. Soil penetration resistance due to compaction from movement of harvesting machinery is more severe in shallower soil layers but in deeper layers the effect of compaction is lower (Fig. 2). Vecbebri study sites show similar results to Ogresgals study site.

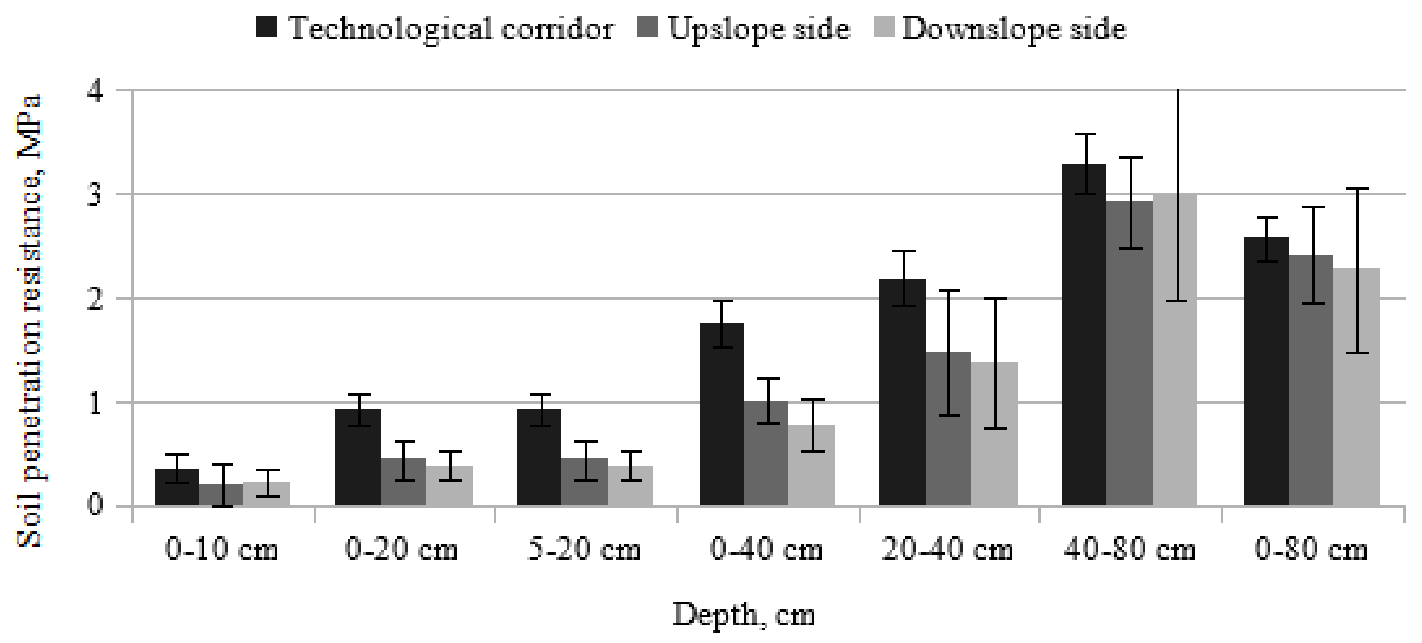

Fig. 2. Soil penetration resistance results at Ogresgals study site

Water permeability properties are determined by analysing the soil samples taken from the technological corridors and adjacent areas. Soil samples were collected in summer 2017 and analysed at the University of Latvia, Faculty of Geography and Earth Sciences. Table 2 shows that the water permeability properties in the technical corridors for almost all plots have decreased, regardless of the depth. In some cases, the results show that water filtration has improved, but these results are likely to be mistaken.

Table 2

Relative water filtration in soil samples between technological corridors and adjacent areas, $\%$

\begin{tabular}{|c|c|c|c|c|c|}
\hline \multirow{2}{*}{ Depth, cm } & Jaunjelgava $_{-}$ & $\begin{array}{c}\text { Jaunjelgava } \\
\mathbf{1}\end{array}$ & $\begin{array}{c}\text { Jaunjelgava }_{-} \\
\mathbf{3}_{-}\end{array}$ & Ogresgals $_{\text { }}$ & Vecbebri $_{-}$ \\
\hline $0-10$ & 96 & 16 & 214 & 27 & 2059 \\
\hline $10-20$ & 60 & 58 & 472 & 38 & 9 \\
\hline $20-40$ & 89 & 32 & 45 & 30 & 22 \\
\hline $40-80$ & 56 & 17 & 1 & 12 & 35 \\
\hline
\end{tabular}

Bulk density of the analysed soil samples is shown in Table 3. The results show that in almost all of the analysed samples from the technological corridors the bulk density of soil is significantly higher than in the adjacent areas. It is noticeable that in the study sites on sand sediments the biggest increase in the soil bulk density is in the deepest layers. In sites on loam sediments the biggest increase is in the shallowest layers.

Technological corridors in the study sites are located perpendicular to slope and in theory compaction of soil should have an impact on the water table level on both sides of the affected area. In Jaunjelgava study sites the water table for the whole study period mostly was deeper than reach of the 
groundwater monitoring wells, so soil compaction did not influence the water table. It should be noted that the period of this study was relatively dry comparing to typical climatic conditions.

Table 3

Increase in soil density on the technological corridor compared to the adjacent area, $\mathrm{kg} \cdot \mathrm{m}^{-3}$

\begin{tabular}{|c|c|c|c|c|c|c|}
\hline $\begin{array}{c}\text { Depth, } \\
\text { cm }\end{array}$ & $\begin{array}{c}\text { Jaunjelgava_ } \\
\mathbf{1}\end{array}$ & $\begin{array}{c}\text { Jaunjelgava } \\
\mathbf{2}\end{array}$ & $\begin{array}{c}\text { Jaunjelgava } \\
\mathbf{3}\end{array}$ & Ogresgals & $\begin{array}{c}\text { Vecbebri } \\
\mathbf{1}\end{array}$ & $\begin{array}{c}\text { Vecbebri } \\
\mathbf{2}\end{array}$ \\
\hline $0-10$ & 101 & 94 & 98 & 134 & 163 & 154 \\
\hline $10-20$ & 102 & 99 & 100 & 126 & 134 & 116 \\
\hline $20-40$ & 105 & 114 & 106 & 101 & 111 & 117 \\
\hline $40-80$ & 154 & 118 & 114 & 105 & 102 & 106 \\
\hline
\end{tabular}

Vecbebri and Ogresgals study sites show similar trends in the water table fluctuations. From September 2017 onwards, the level of the water table in forest stands increased and remained high throughout the winter. In March 2018, the water table level dropped, but during thawing it increased again. In May 2018, with warmer and drier weather conditions, the groundwater levels fell sharply and did not rise again until the end of this observation period. We did not find an evidence that soil compaction caused by harvesting machines affects the water table level differently on both sides of the technological corridor. Only in Vecbebri_1 (Fig. 3) there are periods in winter when the water table level in the territory upslope the technological corridor falls slightly slower than in the territory downslope the technological corridor.

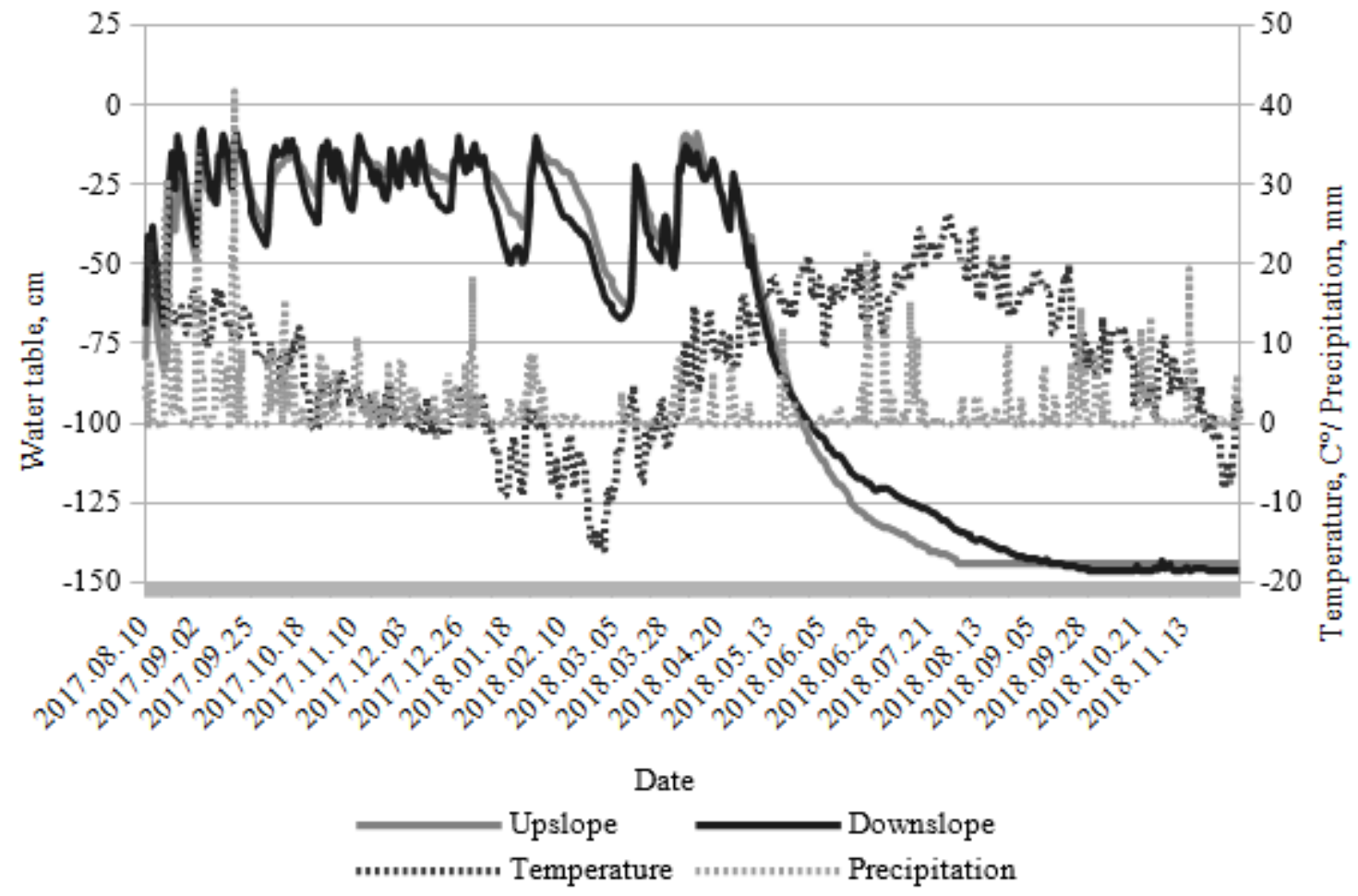

Fig. 3. Water table fluctuations at Vecbebri_1 study site

\section{Conclusions}

1. Under the influence of logging machinery, soil compaction takes place in technological corridors, the soil bulk density increased on average by $10-27 \%$ in different soil layers. Soil compaction is confirmed by both the soil penetration resistance measurements and soil density differences in the technological corridors and the rest of the stand.

2. The most pronounced soil compaction effect on sandy sediments is observed in deeper layers (starting from 20-30 cm), where the soil penetration resistance may increase up to three times, and the soil bulk density may increase by $18-54 \%$. 
3. As the proportion of clay particles in the soil increases, the greatest compaction effect occurs in the shallower soil layers (up to $20 \mathrm{~cm}$ depth). Soil penetration resistance in these layers can increase up to 2.5 times, and the soil bulk density by $16-63 \%$.

4. Soil samples taken from technological corridors also show a decrease in the water permeability rate, however, the results show some misleading information and more samples should be analyzed to get statistically valid conclusions.

5. Water table level measurements do not indicate significant differences between both sides of the technological corridor. It should be noted, however, that the water column in the groundwater monitoring wells has been observed only from late autumn 2017 to early spring 2018. During the remainder of the observation period, due to atypically dry weather conditions, the groundwater level monitoring wells were dry and the water table level in the study sites was deeper than $1.5 \mathrm{~m}$.

\section{Acknowledgements}

The study is implemented within the scope of the memorandum between LSFRI Silava and Joint stock company "Latvia state forests" from 11.10.2011.

\section{References}

[1] Fründ H.C., Averdiek A. Soil aeration and soil water tension in skidding trails during three years after trafficking. Forest Ecology and Management, vol. 380, 2016, pp. 224-231.

[2] Goutal N., Renault P., Ranger J. Forwarder traffic impacted over at least four years soil air composition of two forest soils in northeast France. Geoderma, vol. 193, 2013, pp. 29-40.

[3] Wei L., Hulin F., Chevalier R. etc. Is plant diversity on tractor trails more influenced by disturbance than by soil characteristics? Forest Ecology and Management, vol. 379, 2016, pp. 173-184.

[4] Zālīitis P. Mežs un ūdens. Salaspils: LVMI Silava. 2012.

[5] Zālītis P., Jansons J., Indriksons A. Mežaudžu parametri hidrotehniski meliorētajos mežos pēdējos piecdesmit gados. Mežzinātne, vol. 27(60), 2013, pp. 36-66.

[6] Kozlowski T. T. Responses of Woody Plants to Human-Induced Environmental Stresses: Issues, Problems, and Strategies for Alleviating Stress. Critical Reviews in Plant Sciences, vol. 19(2), 2000, pp. 91-170.

[7] Herbauts J., El Bayad J., Gruber W. Influence of logging traffic on the hydromorphic degradation of acid forest soils developed on loessic loam in middle Belgium. Forest Ecology and Management, vol. 87(1-3), 1996, pp. 193-207.

[8] Koorevaar P., Menelik G., Dirksen C. Elements of soil physics. Elsevier.

[9] Benthaus M., Matthies D. Regeneration befahrener Waldboden. Allgemeine Forstzeitschrift, vol. 48, 1993, pp. 448-451.

[10] Arocena J. Cations in solution from forest soils subjected to forest floor removal and compaction treatments. Forest Ecology and Management, vol. 133(1-2), 2000, pp. 71-80.

[11]Ballard T. M. Impacts of forest management on northern forest soils. Forest Ecology and Management, vol. 133(1-2), 2000, pp. 37-42.

[12] Gebauer R., Martinková M. Effects of pressure on the root systems of Norway spruce plants (Picea abies[L.] Karst.). Journal of Forest Science, vol. 51(No. 6), 2012, pp. 268-275.

[13] Maynard D. G., Senyk J. P. Soil disturbance and five-year tree growth in a montane alternative silvicultural systems (MASS) trial. Forestry Cronicle, vol. 80(5), 2004, pp. 573-582.

[14] Heninger R., Scott W., Dobkowski A. etc. Soil disturbance and 10-year growth response of coast Douglas-fir on nontilled and tilled skid trails in the Oregon Cascades. Canadian Journal of Forest Research, vol. 32(2), 2002, pp. 233-246.

[15] Ebrecht L., Schmidt W. Nitrogen mineralization and vegetation along skidding tracks. Annals of Forest Science, vol. 60(7), 2003, pp. 733-740.

[16] Battigelli J. P., Spence J. R., Langor D. W. etc. Short-term impact of forest soil compaction and organic matter removal on soil mesofauna density and oribatid mite diversity. Canadian Journal of Forest Research, vol. 34(5), 2004, pp. 1136-1149.

[17] Fisher R. F., Binkley D. Ecology and management of forest soils. Wiley-Blackwell. 2012. 
[18] Cornelis W. M., Corluy J., Medina H. etc. A simplified parametric model to describe the magnitude and geometry of soil shrinkage. European Journal of Soil Science, vol. 57(2), 2006, pp. 258-268.

[19] Hansen A., Rotella J. Abiotic factors. M. Hunter (Red.), Maintaining Biodiversity in Forest Ecosystems. Cambridge: University Press. 1999, pp. 161-209.

[20]Zalitis P., Indriksons A. The hydrological properties of waterlogged and drained forests in Latvia. Journal of water and land development, vol. 13, 2009, pp. 69-86.

[21] Hamza M. A., Anderson W. K. Soil compaction in cropping systems: A review of the nature, causes and possible solutions. Soil and Tillage Research, vol. 82(2), 2005, pp. 121-145.

[22] Maanavilja L., Aapala K., Haapalehto T. etc. Impact of drainage and hydrological restoration on vegetation structure in boreal spruce swamp forests. Forest Ecology and Management, vol. 330, 2014, pp. 115-125.

[23] Meirons Z. (s.a.). Kvartāra nogulumi. No Latvijas ǵeoloǵiskā karte, M 1:200000. Rīga: Valsts geologijas dienests. 